DOI 10.17805/ggz.2017.4.5

\title{
Формы охраны природно-культурного наследия и категория культурного ландшафта
}

\author{
М. Е. КУЛЕШОВА
}

РОССИЙСКИЙ НАУЧНО-ИССЛЕДОВАТЕЛЬСКИЙ ИНСТИТУТ

КУЛЬТУРНОГО И ПРИРОДНОГО НАСЛЕДИЯ ИМ. Д. С. ЛИХАЧЕВА

\begin{abstract}
Природное и культурное наследие образуют континуум, сохранение которого предьявляет определенные требования к действующим системам его правовой защиты. Из действующих форм охраны наследия во всей его целостности и комплексности к решению этой задачи наиболее приспособлены национальные парки и музеи-заповедники. Методологической основой сохранения наследия как системы разнообразных и многоуровневых ценностей служит концепция культурного ландшафта.

Ключевые слова: природное и культурное наследие; континуум наследия; культурные ландшафты; особо охраняемые природные территории; объекты культурного наследия; музеи-заповедники; национальные парки; заповедники; зоны охраны; всемирное наследие
\end{abstract}

\section{Forms of Natural and Cultural Heritage Protection and the Category of Cultural Landscape}

\author{
M. E. KULESHOVA

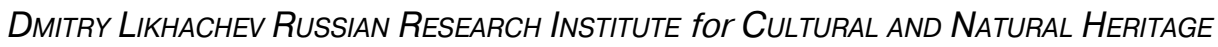

Natural and cultural heritage forms a continuum, the conservation of which makes certain demands on the existing systems of legal protection. The most integrated forms of legal protection for today are national parks and reserve museums. A methodological basis for the conservation of heritage as a system of diverse and multilevel values is the concept of cultural landscape.

Keywords: natural and cultural heritage; heritage continuum; cultural landscapes; protected areas; cultural heritage sites; reserve museums; national parks; nature reserves; buffer zones; world heritage

\section{ЗНАЧЕНИЕ КОНЦЕПТА КУАЬТУРНОГО ААНАШАФТА АИЯ ОХРАНЫ НАСАЕАИЯ}

Природное и культурное наследие в их совокупности понимаются нами как система ценностей и информационный потенциал, запечатленный в событиях, процессах, материальных объектах, морально-этических нормах, научных и философских представлениях, который востребуется человеческими обществами для своего существования и развития, и сохраняется для передачи последующим поколениям (Кулешова, 1994; Культурный ландшафт ... , 2004). Культурное и природное наследие обладают континуальностью, взаимозависимостью, взаимообусловленностью.

Культурный ландшафт в качестве объекта наследия нередко соединяет в себе все эти аспекты, поскольку является природно-культурным территориальным комплексом, сформировавшимся в результате эволюционного взаимодействия природы и человека, его социокультурной и хозяйственной деятельности, и состоящим из характерных сочетаний природных и культурных компонентов в их устойчивой взаимосвязи и взаимообусловленности (Культурный ландшафт .., 2004, Сельские культурные ..., 2013). В общем случае под культурными ландшафтами понимаются целостные культурно-природные территориальные комплексы, в которых природа и культура в процессе их взаимодействия, или сотворчества, образовали и продолжают являть некие характерные, визуально считываемые, вербально и картографически фиксируемые, 
регистрируемые в ощущениях сочетания. От девственного ландшафта до индустриального - великое множество вариаций, в зависимости от типа ландшафта и его состояния ведущими ландшафтообразующими процессами могут быть как природные, так и культурные. Ауховная культура, знания, традиции, технологии - этнические, конфессиональные, классово-кастовые, профессионально-корпоративные - вносят свою лепту в формирование культурных ландшафтов так же, как и природные процессы. Какова роль того или иного природного или культурного компонента, либо процесса, какова формула, принцип описания, управления или сохранения территориального комплекса - зависит от объективно заданной реальности конкретного территориального комплекса, и от исследователя или исследовательской школы.

Сформулированное и широко апробированное в Институте Наследия в 19922013 гг. представление о культурном ландшафте позволяет на практике соблюсти принцип континуальности природного и культурного начал в наследии, а также принцип территориальной целостности и подлинности среды бытования отдельных элементов наследия. Российский научно-исследовательский институт культурного и природного наследия, созданный под руководством Ю. А. Веденина в апреле 1992 г., был в свое время явлением мирового уровня - других подобных научно-исследовательских центров, целенаправленно изучающих природное и культурное наследие в их совокупности и взаимосвязи, просто не было в мире. Изначальная ориентация на комплексный, системный подход к наследию означала, что привычное ведомственное разделение наследия на природное и культурное, материальное и нематериальное, движимое и недвижимое недостаточно для решения многих прикладных задач (Веденин, 2012).

Велико количество исследователей, привнесших свое видение в концепт культурного ландшафта, с историей вопроса можно ознакомиться по историографическим разделам фундаментальных работ В. Н. Калуцкова, В. Н. Стрелецкого, М. В. Рагулиной, другим историографическим публикациям, однако специального историографического исследования по культурным ландшафтам еще не написано.

В 1990-е годы получило развитие и стало весьма востребованным направление, называемое информационно-аксиологическим, а также ноосферным, где культурный ландшафт, в соответствии с Конвенцией ЮНЕСКО о всемирном наследии, рассматривается как феномен наследия, как источник информации, как результат сотворчества человека и природы (Веденин, Кулешова, 2004; Туровский, 1998). Направление развивалось на базе исследований Института Наследия, возглавляемого Ю. А. Ведениным в 1992-2013 гг., и оказало огромное влияние на легитимизацию понятия. В его рамках заложено основание информационной парадигмы ландшафта, разработаны и внедрены понятия о культурном каркасе, о природно-культурном каркасе, о культурноландшафтном районировании, о роли традиций и новаций в формировании культурного ландшафта, а также о роли искусства в этом процессе, разработаны типологии культурных ландшафтов и форматы структурного описания отдельных их типов для целей выявления предмета охраны, изучено влияние концепта культурного ландшафта на формирование Списка всемирного наследия.

В отечественном законодательстве культурный ландшафт представлен как возможный объект культурного наследия (№ 73-Ф3 «Об объектах культурного наследия (памятниках истории и культуры) народов Российской Федерации», ст. 3); как одно из оснований создания особо охраняемых природных территорий (№ 33-Ф3 «Об особо охраняемых природных территориях», ст. 2); как повод для отнесения земель к кате- 
гории особо ценных (Земельный кодекс РФ, ст. 100). Объектом культурного наследия культурный ландшафт признается путем придания ему статуса достопримечательного места при экспертном подтверждении его особой историко-культурной ценности. Основными организационными формами охраны культурных ландшафтов в России служат национальные парки, относящиеся к особо охраняемым природным территориям федерального уровня, и музеи-заповедники, относящиеся к учреждениям культуры (Кулешова, Веденин, 2009). Аругие категории особо охраняемых природных территорий в некоторых случаях также могут служить защитой для культурных ландшафтов. Кроме того, опосредованная охрана культурных ландшафтов осуществляется при создании зон охраны памятников культуры и ансамблей.

\section{КОНТИНУУМ ПРИРОАНЫХ И КУАБТУРНЫХ ЦЕННОСТЕЙ НАСАЕАИЯ. ПРИРОАНОЕ НАСАЕАИЕ КАК КУАБТУРНЫЙ ФЕНОМЕН}

Аксиология природных ценностей наследия есть производное определенной культуры - например, применяемый ЮНЕСКО к объектам природного наследия критерий vii («выдающиеся феномены красоты и эстетической ценности») есть в чистом виде культурная интерпретация природного достояния. Природное наследие - осмысленный и присвоенный человеком природный капитал, включая составляющие его генофонд, ценофонд и геофонд, то есть биологическое и ландшафтное разнообразие планеты (Кулешова, 1994). Этот капитал, с точки зрения его возможного использования, выполняет важнейшие функции: он является банком данных о важнейших процессах геосферы, источником возобновления ценнейших хозяйственных ресурсов, включая рекреационные, важнейшим фактором стабилизации экологических параметров среды. Объекты природного наследия выполняют важнейшие культурные функции, участвуют в процессах самоидентификации народов, нередко являются священными и тотемными, и одновременно имеют огромное значение для науки.

Многие природные феномены обладают исключительной культурной ценностью и признаны культурным наследием (например, священные горы, рощи, источники вод), и, напротив, множество памятников культуры лишаются своей целостности и аутентичности, будучи лишены своего природного и ландшафтного контекста. Культурное наследие нередко «срослось» со своей природной субстанцией и неотделимо от нее (например, пещерные монастыри, петроглифы, многие традиционные промыслы, и даже целые системы жилищ, созданных из находящихся по месту селитьбы материалов).

Социокультурная деятельность тяготеет к узловым структурам природного каркаса (Кулешова, 2007) и очагам биоразнообразия. Некоторые формы социокультурной деятельности, в частности сакрализация пространства у многих сибирских народов, своим прямым эффектом имеет защиту природного наследия.

Наконец, выявление, изучение и сохранение природного наследия во многих случаях опирается на традиционные знания коренных народов и выработанные системы взаимоотношений локальных сообществ со своей природной ресурсной базой, причем они могут носить не только экономический, но одновременно сакральный характер. Аля коренных народов Севера вопросы жизнеобеспечения и духовные практики образуют единое целое (Наши льды ..., 2013)

Граница между природным и культурным наследием достаточно континуальна, наследие - едино и его разделение оправдано лишь тем, что действующие системы управления опираются на отраслевые принципы. В природоохранном законодатель- 
стве, в частности, в преамбуле федерального закона «Об особо охраняемых природных территориях», зафиксирован культурный потенциал природных объектов, а именно указывается, что такие объекты «имеют особое природоохранное, научное, культурное, эстетическое, рекреационное и оздоровительное значение». Термин «природное наследие» довольно редко используется в нормативных природоохранных документах национального уровня. Он более известен в связи с применением Конвенции о всемирном наследии (Convention..., 1972). Однако это не означает, что природному наследию не уделяется должного внимания в отечественном законодательстве. Российская практика охраны природного наследия оперирует такими понятиями как «особо охраняемые природные территории», «Красные книги» исчезающих видов животных и растений, «биоразнообразие» и др. В преамбуле федерального закона №33-Ф3 «Об особо охраняемых природных территориях» дано их общее определение, которое вполне соотносится с содержанием понятия «природное наследие», зафиксированным в Конвенции о всемирном наследии. Отмечено, что особо охраняемые природные территории относятся к объектам общенационального достояния.

В п. 1 ст. 2 № 33-Ф3, который был добавлен в 2013 г., обозначены условия принятия решений о создании охраняемых территорий, в этих «условиях» постоянно фигурирует культурная ценность природных объектов и впервые в природоохранном нормотворчестве нашей страны в 2013 г. появляется понятие о культурных ландшафтах. В частности, «при принятии решений о создании особо охраняемых природных территорий учитывается: «б) наличие в границах соответствующей территории участков природных ландшафтов и культурных ландшафтов (здесь и далее выделено мною. - M. К.), представляющих собой особую эстетическую, научную и культурную ценность» (с. 3).

В 2011 г. Правительством РФ утверждена «Концепция развития системы особо охраняемых природных территорий федерального значения на период до 2020 г», где задачи сохранения объектов культурного наследия выделены в самостоятельный раздел. Они включают в себя «выявление, обследование и оценку состояния памятников истории и культуры; <...> постоянное наблюдение за состоянием памятников истории и культуры, а также культурно-ландшафтных комплексов; <...> работы по восстановлению и поддержанию в традиционном состоянии приоритетных культурно-ландшафтных комплексов; <...> регламентацию режима особо охраняемых природных территорий с учетом интересов сохранения объектов культурного наследия; <...> содействие восстановлению и развитию традиционных промыслов и ремесел», разработку методических рекомендаций «по вопросам сохранения культурных ландшафтов, реставрации, восстановления и использования памятников истории и культуры на территориях национальных парков», внедрение задач охраны наследия в федеральные и региональные целевые программы (с. 14-15). В утвержденной Концепции обращает на себя внимание подчеркнутый интерес к культурным ландшафтам, а также понимание важности живой традиционной культуры, в частности - промыслов и ремесел.

\section{ОРГАНИЗАЦИОННО-ПРАВОВЫЕ ФОРМЫ ОХРАНЫ НАСАЕАИЯ}

В настоящее время в России насчитывается более 100 государственных природных заповедника, полсотни национальных парков и порядка 70 государственных природных заказников федерального значения. В последние годы были созданы и национальные парки «Шантарские острова» (Хабаровский край), «Чикой» (Забайкалье), 
«Берингия» (Чукотка), «Онежское Поморье» (Архангельская область). Общая площадь всех охраняемых природных территорий России составляет около $12 \%$ от площади РФ, т. е. более 200 млн га (Госдоклад ... , 2016).

Географическое распределение особо охраняемых природных территорий федерального статуса по территории страны имеет свои особенности. Более равномерно и с достаточно высокой плотностью они распределены по основной части европей- ской территории, что связано с ее высокой освоенностью, ведь выявление и постанов- ка на охрану объектов наследия определяется не только критериями их ценности, но и уязвимостью под влиянием нерегулируемой антропогенной нагрузки и конфликтных видов природопользования. Вдоль Урала эти формы охраны наследия образуют явную концентрацию - не только в связи со значимой морфометрической структурой, но по месту прохождения важной исторической границы и культурного градиента. За Уралом федеральные охраняемые территории тяготеют к крупным приморским экотонам вдоль арктических морей и восточной оконечности евразийского континента, а также к горным барьерам юга Сибири, Аальнего Востока и тектонической впадине Байкала с окрестностями.

На некоторые категории особо охраняемых природных территорий, в частности на национальные парки, законодательством возложены задачи сохранения как природного наследия, так и «историко-культурных комплексов и объектов» (ст. 13, №33-Ф3); в ряду их функциональных зон предусмотрено выделение зоны охраны объектов культурного наследия и зоны традиционного природопользования коренных малочисленных народов (ст. 15 № 33-Ф3). Методически эти организационноправовые формы охраны наиболее интересны, в них природно-культурный континуум наследия выражен ярче, в них выделяются культурно-ландшафтные комплексы наследия, что подтверждает собственный многолетний опыт сотрудничества автора со многими национальными парками, а также участие в 2014-2015 гг. в проекте экоцентра «Заповедники» по инвентаризации и систематизации объектов культурного наследия в национальных парках России.

Так, на крайнем севере страны, в национальном парке «Русская Арктика» наряду с популяциями белых медведей, северных оленей, крупнейшими птичьими базарами, лежками многочисленных ластоногих, территория хранит следы первооткрывателей Севера (в частности Баренца, Русанова, Седова), далеких экспедиций, часто трагических, изобилует памятниками истории отечественной науки и объектами военной истории. В Сочинском национальном парке, крае водопадов, каньонов и пещер, наряду с уникальными для России рефугиумами колхидской флоры, местообитаниями леопарда и других редких видов биоты, находятся уникальные археологические комплексы дольменов, руины древнехристианских храмов, свидетельства древнего расселения и природопользования. В границах территории национального парка «Угра» в центре европейской России - не только уникальные реликтовые широколиствен- ные леса и эндемичные виды биоты, но и монастыри; река Угра в своем нижнем течении получила название Пояса Богородицы - здесь были остановлены орды хана Ахмата в 1480 г., что ознаменовалось массовым строительством богородичных храмов по Угре.

Озеро Байкал, известное своими уникальными гидробионтами, запасами и чистотой своих вод, биоразнообразием окрестных экосистем в границах целого ряда заповедников и национальных парков, одновременно является основным культовым объектом бурятского народа, окружающие его угодья плотно «заселены» персонажами 
локальных культов, здесь сохраняются древние традиции номадической культуры. Во вновь созданный национальный парк «Чикой», помимо уникальных южно-таежных биоценозов и местообитаний краснокнижных видов биоты, включены культурные пространства старообрядцев «семейских», зачисленные в международный список объектов нематериального наследия ЮНЕСКО (хотя Россия, к великому сожалению, пока не решается присоединиться к Конвенции о нематериальном наследии).

Национальный парк «Берингия» на Чукотском полуострове включает сегодня ключевые местообитания ластоногих, китов и птиц, но он начинался с регионального этно-природного парка, в котором ведущими задачами были не только охрана биоты, но сохранение уникального этнического (эскимосов и чукчей) и археологического наследия, культуры древних охотников (Богословская, Веденин, 2003). В нем находятся места традиционного природопользования и святилища коренных народов, включая всемирно известную Китовую аллею. В границах национального парка насчитывается сегодня несколько десятков объектов культурного наследия, связанных с историей коренного населения, включая древние поселения, становища, охотничьи стоянки, стойбища, могильники, памятники из китовых костей.

Наряду с национальными парками многие государственные природные заповедники также представляют исключительный интерес с точки зрения их историко-культурного потенциала, хотя действующее законодательство не учитывает этих аспектов и не оговаривает участие природных заповедников в сохранении культурного наследия. Так, природный заповедник Шульган-Таш в Башкирии известен не только своими природными достопримечательностями, но и наскальными палеолитическими росписями Каповой пещеры, а также исторической традицией бортничества, позволившей сохранить здесь уникальные местообитания бурзянской бортевой пчелы. Аля этой природной охраняемой территории готовятся документы по включению ее в объекты всемирного наследия по категории «смешанное природно-культурное наследие», причем культурное наследие рассматривается в контексте культурного ландшафта.

В 1998 г. было предпринято первое и единственное систематизированное исследование историко-культурного потенциала государственных природных заповедников (Матюшкин, 1998). Из 99 существовавших на тот момент заповедников (а за прошедшие 15 лет их количество увеличилось всего на единицы, поскольку наступила «эра» национальных парков) из 60-ти были получены данные о наличии историко-культурных объектов (около 6 тыс. единиц). В их числе - древние поселения, памятники архитектуры, погребальные комплексы, следы древнего природопользования, объекты живой традиционной культуры.

Например, в Алтайском заповеднике (входит в объект всемирного наследия «Золотые горы Алтай») только благодаря включению в программы охраны наследия местных общин с их традиционными хозяйственными и культовыми практиками новому руководству заповедника удалось разрешить многие природоохранные конфликты на этой территории. Наряду с местными обычаями и традициями Алтайский заповедник известен своими археологическими памятниками, включая древние оросительные системы, могильники, святилища. В Жигулевском заповеднике и сопредельном с ним национальном парке «Самарская Аука» находится целая серия уникальных памятников горной добычи известняка и битуминозных песчаников, включая штольни, карьеры, «гудронные озера». В некоторых штольнях теперь расселились краснокнижные виды летучих мышей. Кроме того, эта территория богата памятниками археологии (из них 
наиболее известен Муромский городок), архитектуры и истории, исторические предания фиксируются богатой и разнообразной топонимикой.

Заповедник «Убсунурская котловина», включенный в Список всемирного наследия ЮНЕСКО за исключительное разнообразие экосистем (от тайги и горной тундры до степей и пустыни) и наличие ключевых местообитаний редких видов биоты, одновременно представляет уникальный пример живого традиционного землепользования кочевых народов. Здесь сохраняется тувинское искусство горлового пения и наблюдается исключительная концентрация археологических памятников - курганных комплексов, наскальных рисунков, каменных изваяний. Эта территория имеет основания быть реноминированной в объект смешанного природно-культурного наследия ЮНЕСКО. Многие другие природные заповедники обладают значительными историко-культурными богатствами - Воронежский, Ильменский, Кавказский, «Кивач», Командорский, Мордовский, Тебердинский, Усть-Иенский, Чазы и др.

В системе охраны культурного наследия, так же как и в системе управления особо охраняемыми природными территориями, есть представление о культурной ценности природных объектов и зависимости многих культурных раритетов от состояния и характеристик вмещающего ландшафта. Наиболее важным положением федерального законодательства здесь следует признать установление такого вида объектов культурного наследия, как достопримечательные места, и возможность отнесения к данному виду таких феноменов, как культурные и природные ландшафты (статья 3 №73-Ф3). Аля объектов культурного наследия предусматривается создание зон охраны, в ряду которых - охранная зона, зона регулирования застройки и хозяйственной деятельности и, наконец, зона охраняемого природного ландшафта, функция которой - «сохранение (регенерация) природного ландшафта, включая долины рек, водоемы, леса и открытые пространства, связанные композиционно с объектами культурного наследия». Однако наибольшим управленческим потенциалом и опытом сохранения природных достопримечательностей обладает особый тип учреждений культуры, с 1960-х годов успешно контролирующих обширные территории с их природно-культурным континуумом наследия, - музеи-заповедники, деятельность которых нынче регулируется законом № 54-Ф3 «О музейном фонде и музеях в Российской Федерации».

От степени сохранности природных комплексов и достопримечательностей нередко зависит аутентичность историко-культурного ландшафта и культурного пространства в музеях-заповедниках. Например, для Ясной Поляны это - фрагменты старовозрастных широколиственных лесов, свидетельств засечной черты, древнейшего оборонного рубежа - Тульских засек. Аля Тихого Аона, Шолоховского музея-заповедника - участки ковыльных степей, меловой флоры речных крутосклонов, займищ и речных яров Аона, редких видов степной орнитофауны, саженых сосновых боров. Аля пушкинского Михайловского - колония серых цапель, «зуев» на местном наречии, давшая название предшественнице Михайловского - деревне Зуево, сложные сосновые боры и дремучие хвойно-широколиственные леса, изгибы речки Сороти и живописные озера с их водными и околоводными обитателями. Аля Соловков ключевые стации обитания беломорского кита - белухи, уникальные колонии крачек, места гнездования гаги и других редких водоплавающих, разнообразие форм водно-ледникового и морского рельефа, обилие озерных систем, и т. А. В музее-заповеднике «Куликово поле» основные усилия направлены на реконструкцию поля битвы, а именно: восстановление ковыльных степей с колками дубрав; здесь проводятся 
работы по восстановлению популяций целого ряда редких степных растений. В музеезаповеднике «Аивногорье» наряду с пещерными монастырями и древней Маяцкой крепостью основное внимание привлекают меловые останцы - «дивы», разноцветье степных балок и каньонов, широкие просторы заливных лугов Аона и Тихой Сосны.

Одной из ключевых функций музеев-заповедников, для которых культурные и природные компоненты наследия составляют единое неделимое целое, должны стать комплексная охрана ландшафтов и презентация природного разнообразия России в качестве ее важнейшей культурной характеристики. Необходимо предпринять специальное исследование этих форм организации охраны наследия для выявления их культурно-экологического, научного и средообразующего потенциала. Управление объектами природного и культурного наследия России должно исходить из условий их целостности и взаимообусловленности на основании межведомственных соглашений, совместных межведомственных программ по сохранению и использованию наследия и широкого участия тех, чьи предки веками создавали и поддерживали систему ценностей, определяемых сегодня как наследие.

\section{ТЕРРИТОРИИ ТРАДИЦИОННОГО ПРИРОАОПОАБЗОВАНИЯ И КУАБТУРНЫЕ ААНАШАФТЫ}

Важная роль в сохранении местообитаний редких видов биоты и ландшафтного разнообразия страны может принадлежать территориям традиционного природопользования, поскольку традиционный хозяйственный уклад и культурные практики экофильных народов предполагают щадящие способы освоения угодий и поддержание биоразнообразия, о чем уже упоминалось выше. Территории традиционного природопользования (ТТП) концептуально очень близки культурно-ландшафтной парадигме, если понимать под ними не только правовую форму охраны определенных участков территории, но и ту содержательную основу, ради которой устанавливается правовой статус. Закон «О территориях традиционного природопользования коренных малочисленных народов Севера, Сибири и Аальнего Востока Российской Федерации» (№ 49-Ф3) был принят в 2001 г., ТТП трактовались в нем как особо охраняемые природные территории, однако эта законодательная инициатива не повлияла на содержание другого закона «Об особо охраняемых природных территориях» (№33-Ф3), где эта категория отмечена не была. Многочисленные нестыковки с корреспондирующими законодательными актами, буквальное «бойкотирование» закона о ТТП на федеральном уровне не позволили в полной мере использовать его Аля защиты жизненного пространства малочисленных народов российского Севера. Но мы обратим внимание не на правовую, а на сущностную сторону ТТП - на их фактуру.

Хотя основной массив нормативно-правовых документов по ТТП не содержит понятия «культурный ландшафт», их пообъектный состав можно рассматривать в качестве аналога топосной структуры культурного ландшафта. Особенно четко это прослеживается в исследованиях $\Lambda$. С. Богословской (Богословская, 2014), относящей к ТТП: 1) землю родного селения, 2) земли, где захоронены предки, 3) священные места - территории, водные пространства и природные объекты, часто отмеченные особыми ритуальными сооружениями, 4) заповедные земли и водные пространства, 5) охотничьи угодья, рыбопромысловые участки, оленьи пастбища, маршруты кочевок, традиционные транспортные пути, резервные земли. Она ставит знак равенства между ТТП и культурными ландшафтами: «Территории традиционного природо- 
пользования (ТТП) коренного населения Севера - это особый вид сельских культурных ландшафтов, неразрывно связанный с внутриэтнической и/или внутрипопуляционной структурой традиционных сообществ» (п. 1.2); «Пространственное воплощение локальных культур представляют культурные ландшафты, или ТТП, - освоенные людьми территории вместе с их флорой и фауной» (п. 3.2); «Принципиальное отличие культурных ландшафтов (ТТП) коренных малочисленных народов Севера от культурных ландшафтов других этносов - их визуальная неотличимость от окружающей нетронутой природы» (п. 4.4). Богословская первая обратила внимание на те особенности ТТП, которые в современной законотворческой практике еще не вполне осмыслены, но которые наиболее адекватно определяют предмет защиты исконной среды обитания коренных народов. Практика создания ТТП регионального уровня в Якутии, Югре, Приморском крае показывает, что эта правовая форма охраны наиболее соответствует целям комплексной защиты природного и культурного, материального и нематериального наследия в его целостности и взаимообусловленности.

В статье 9 № 49-Ф3 в числе условий, детерминирующих размеры и границы ТТП, названы сохранение биоразнообразия и сохранение целостности объектов историкокультурного наследия, что подтверждает наличие природно-культурного континуума наследия и вневедомственный характер такого феномена, как ТТП. То же самое подтверждает статья 4 № 49-Ф3, где обозначены цели закона: сохранение исконной среды обитания и традиционного образа жизни малочисленных народов, сохранение и развитие самобытной культуры, сохранение биоразнообразия.

\section{ВСЕМИРНОЕ НАСАЕАИЕ И КУ АЬТУРНЫЕ ААНАШАФТЫ КАК ОСНОВАНИЕ}

\section{ЦЕАОСТНОСТИ КОНТИНУУМА ПРИРОАНОГО И КУ АЬТУРНОГО НАСАЕАИЯ}

Природное и культурное наследие составляют феномены различного иерархического уровня - от общемирового до локального. Так, на мировом уровне объекты наследия фиксируются главным (но не единственным) образом в рамках Списка всемирного наследия (для сохранения культурных ландшафтов и культурных пространств имеют большое значение Европейская конвенция о ландшафтах, 2000, Конвенция о нематериальном наследии человечества, 2003, Программа ЮНЕСКО «Человек и биосфера» и целый ряд других международных соглашений и актов). В настоящее время от России в состав объектов всемирного наследия ЮНЕСКО входят 27 территорий -17 культурных и 10 природных. Значительное число российских объектов всемирного природного наследия обладает также историко-культурной ценностью. О заповедниках Алтайском и Убсунурской котловине, Сочинском национальном парке уже говорилось. Аевственные леса Коми вкдючают Печоро-Илычский заповедник, Национальный парк Югыд-Ва и несколько заказников, представляющих тундровые и таежные экосистемы Северного Урала с обилием водно-болотных угодий. Здесь же находятся интересные историко-культурные объекты - святилища народа манси, включая священные горы и каменные останцы, старинные дороги, тракты и просеки, палеолитические стоянки (Медвежья пещера), объекты традиционного природопользования - стойбища оленеводов, следы старообрядческих скитов, старых лесных и горнодобывающих промыслов.

Озеро Байкал, находящееся под охраной нескольких заповедников и национальных парков, - не только природное наследие с общеизвестными уникальными запасами пресной воды, брендовыми видами биоты - байкальской нерпой и байкальским омулем, уникальными геосистемами и биоценозами, но и священное место бу- 
рят, сойотов и монголов, территория сохранившихся традиционных практик природопользования и следов древнего природопользования, а также средоточие разнообразных памятников археологии. Все эти сочетания разнообразных взаимосвязанных элементов в границах целостного территориального комплекса свидетельствуют о целесообразности применения ландшафтного подхода к наследию и использовании концепции культурного ландшафта для презентации подобных территориальных комплексов.

Культурные ландшафты, формально относимые руководящими документами ЮНЕСКО к культурному наследию, начиная с 1992 г. особо выделяются в Списке всемирного наследия (http://whc.unesco.org/en/list/). В определении ЮНЕСКО обозначено, что они представляют совместное произведение человека и природы (Operational..., 2008); следовательно, несмотря на свою формальную принадлежность к культурному наследию, они являются сложными переходными формами, где природа и культура взаимообусловлены. Это не просто «смесь» из природных и культурных компонентов и ценностей, а целостные генетически неоднородные территориальные комплексы наследия.

В России к культурным ландшафтам, объектам всемирного культурного наследия, официально отнесена Куршская коса - совместный объект России и Аитвы, который на территории России находится под охраной одноименного национального парка в ведении Минприроды РФ. Это древний миграционный путь не только отдельных видов биоты, но и целых этнических общностей, с сохранившимися традиционными рыбацкими поселениями и уникальными дюнными комплексами, которые испытали негативное антропогенное воздействие в XIX веке и были дестабилизированы, а затем закреплены инновационными по тем временам способами и ныне представляют сформировавшиеся лесные псаммофитные сообщества. К культурным ландшафтам отнесен и Херсонес Таврический, представленный в Список всемирного наследия ЮНЕСКО в 2013г. от Украины - как территория древнего города, так и его хора наряду с археологическими древностями Боспорского царства демонстрируют существовавшие на то время системы природопользования и включают в себя природные образования, характеризующие ландшафтное своеобразие Крыма.

Культурным ландшафтом следовало бы признать и Соловецкий архипелаг (с 1960-х годов здесь действует музей-заповедник, с 1992 г. возобновлен Спасо-Преображенский монастырь, в 2015-2016 гг. планировалось создание федерального заказника). Этот вывод неоднократно был зафиксирован в научных публикациях (Кулешова, 2012), об этом напрямую сказано в последнем отчете миссии ЮНЕСКО, провоАившейся в августе 2013 г. (Report.., 2013: 5): «Основополагающим принципом всех управленческих решений должно стать понимание Соловецких островов - объекта всемирного наследия - как культурного ландшафта, включая взаимодействие человека с окружающей средой». В документе подчеркивается единство не только природного и культурного, но и материального и нематериального наследия в культурном ландшафте.

На основании концепции культурного ландшафта в 2013 г. при непосредственном участии автора были начаты работы по выдвижению в объекты всемирного культурного наследия новой номинации «Заповеданное Кенозерье» в границах особо охраняемой природной территории - национального парка «Кенозерский». Уникальное собрание часовен, святых рощ, шедевров деревянной храмовой архитектуры, крестьянских поселений с прилегающими хозяйственными угодьями в окружении таежных 
лесов, многочисленных озер и болот создало выдающийся крестьянский ландшафт северной России, ставший реликтом под влиянием необратимых процессов глобализации (Кулешова, 2012).

Берингия также имеет несомненные основания для отнесения к объектам всемирного наследия, причем культурно-ландшафтный подход к этой территории мог бы представить ее достоинства наиболее ярко. Берингия - уникальный ландшафтный объект (Иицом к морю ..., 2016), который может быть номинирован по нескольким критериям «выдающейся универсальной ценности всемирного наследия». Этот гигантский «поворотный мыс» и культурный «перекресток», как мы полагаем, содержит уникальные свидетельства древних культур, осваивавших ландшафт, служит выдающимся по своей репрезентативности примером традиционного природопользования коренных народов Севера, уязвимого под влиянием глобальных изменений окружающей среды, ассоциируется с базовыми космогоническими представлениями коренных народов Чукотки. Он иллюстрирует один из важнейших этапов истории Земли: процесс формирования профиля материковой Евразии и ее шельфа в условиях рифтовой зоны, включает важнейшие местообитания и пути миграций ключевых видов биоты. Своеобразным аспектом традиционного природопользования является формирование сезонных ледовых ландшафтов (Крупник, 2013), исследование которых в качестве феноменов наследия началось именно с Берингии.

У каждой страны и народа - свои предпочтения в отборе представительских ценностей, выдвигаемых в Список всемирного наследия, свои символы национальной самоидентификации. Так, для Великобритании в ряду объектов, претендующих называться культурными ландшафтами, на одно из первых мест выходят фабричные поселки времен промышленной революции с их индустриальным ландшафтами, для Нидерландов характерны польдеры и различные водорегулирующие системы. В Китае одна из главных тем - священные горы. В Греции - археология и святые места. В Марокко - городские медины. От США превосходящим числом представлены национальные парки, что следует рассматривать не только как радение о природе, но как своеобразную культурную декларацию, поскольку эта страна явилась центром происхождения данного феномена. Что же определяет своеобразие России? Судя по составу российских объектов, большую роль в формировании ее международного образа играют природные номинации, разнообразие природного наследия - ее «культурный багаж», а обширность территории накладывает ответственность за поддержание глобальных экологических процессов (Родоман, 2016). Что касается состава объектов культурного наследия (преимущественно кремли, дворцы, монастыри) - он демонстрирует, наряду с культурными достижениями, ее имперский характер. Но культура России - это гораздо большее, и концепция культурных ландшафтов является инструментом к постижению ее непреходящих ценностей.

\section{СПИСОК АИТЕРАТУРЫ}

Государственный доклад «О состоянии и об охране окружающей среды Российской Федерации в 2015 г.» Минприроды РФ, 2016.

Концепция развития системы особо охраняемых природных территорий на период до 2020 г. Утверждена распоряжением Правительства РФ от 22.12.2011 № 2322-р. 32 с.

Богословская, $\Lambda$. С. (2014) К концепции законопроекта «О территориях традиционного природопользования коренных малочисленных народов (и других малочисленных этнических общностей) Севера, Сибири и Аальнего Востока РФ»/ Материалы парламентских слушаний 16.05.2014. - М. : Совет Федерации (в рукописи). 
Богословская, А. С., Веденин, Ю. А. (2003) Российская «Берингия»: национальные и международные аспекты // Межд. конф. «Ани Беринги». М. С. 10-22.

Веденин, Ю. А. (2012) Изучение, сохранение и актуализация наследия как фактора устойчивого развития районов // Россия и ее регионы: интеграционный потенциал, риски, пути перехода к устойчивому развитию. М. : Товарищество научных изданий КМК. С. 85-111.

Веденин, Ю. А., Кулешова, М. Е. (2004) Культурные ландшафты как категория наследия // Культурный ландшафт как объект наследия. М. : Институт Наследия; СПб. : Амитрий Буланин. C. 13-36.

Калуцков, В. Н. (2008) Аандшафт в культурной географии. М. : Новый хронограф. 320 с.

Крупник, И. И. (2013) Об изучении ледовых культурных ландшафтов // Наши льды, снега и ветры. Народные и научные знания о ледовых ландшафтах и климате Восточной Чукотки. М. : Институт Наследия. С. 18-23.

Кулешова, М. Е. (1994) Понятийно-терминологическая система «Природное и культурное наследие»: содержание и основные понятия // Уникальные территории в культурном и природном наследии регионов. М. : РНИИ культурного и природного наследия. С. 40-46.

Кулешова, М. Е. (2007) Наследие и природно-культурный каркас территорий // Известия Самарского научного центра РАН. № 1. С. 7-14.

Кулешова, М. Е. (2012) Культурные ландшафты и перспективы расширения представительства России в Списке всемирного наследия // Известия Русского географического общества. Т. 144. № 5 . С. $71-80$.

Кулешова, М. Е., Веденин, Ю. А. (2009) Правовое обеспечение сохранения и использова- ния культурного и природного наследия в России // Право и культура. М. : ИзА-во РАГС. С. 361390.

Культурный ландшафт как объект наследия (2004) / под ред. Ю. А. Веденина, М. Е. Кулешовой. М. : Институт Наследия ; СПб. : Амитрий Буланин. 620 с. $648 \mathrm{c}$.

Иицом к морю (2016) : Памяти Аюдмилы Богословской / сост. и отв. ред. И. И. Крупник. М.

Матюшкин, И. Е. (1998) Памятники историко-культурного наследия на территориях государственных природных заповедников (краткий обзор). Вып. 1. М. : Экоцентр «Заповедники». $41 \mathrm{c.}$

Наши льды, снега и ветры (2013) : Народные и научные знания о ледовых ландшафтах и климате Восточной Чукотки / сост. и ред. $\Lambda$. С. Богословская, И. И. Крупник. М. : Институт Наследия. 360 с.

Рагулина, М. В. (2004) Культурная география: теория, методы, региональный синтез. Иркутск : ИГ СО РАН. 172 с.

Сельские культурные ландшафты (2013) : рекомендации по сохранению и использованию / под ред. М. Е. Кулешовой. М. : Экоцентр «Заповедники». 220 с.

Родоман, Б. Б. (2016) Экологическая специализация - желательное будущее для большей части России // Известия РАН. Серия географическая. № 4. С. 140-148.

Стрелецкий, В. Н. (2002) Географическое пространство и культура: мировоззренческие установки и исследовательские парадигмы в культурной географии // Известия АН. Серия географическая. № 4. С. 18-28.

Туровский, Р. Ф. (1998) Культурные ландшафты России. М. : Ин-т Наследия. 210 с. Convention concerning the protection of the world cultural and natural heritage. (1972) UNESCO. $16 \mathrm{p}$.

Operational Guidelines for the Implementation of the World Heritage Convention. (2008) Annex 3. UNESCO. WHC. 08/01. P. 85-92 (online). URL: http://whc.unesco.org/en/guidelines/ (access ed 13.06.2017).

Report of the joint UNESCO-ICCROM-ICOMOS reactive monitoring mission to the cultural and historic ensemble of the Solovetsky Islands. (2013) Russian Federation, 5-14 August. 
Кулешова Марина Евгеньевна - кандидат географических наук, специалист по культурным лндшафтам, объектам всемирного наследия, особо охраняемым территориям и музеям-заповедникам, другим организационно-правовым формам охраны культурного и природного наследия, заведующий Отделом культурных ландшафтов и традиционного природопользования Российского научно-исследовательского института культурного и природного наследия им. А. С. Аихачева (1992-2016 гг.). Адрес: Москва, Берсеневская набережная, 20. Тел.: +7 (495) 686-13-19; мб.+ 7 (917) 592-14-86. Эл. адрес: culturalandscape@mail.ru

Kuleshova Marina Evgenievna, Candidate of Science (geography), expert on the cultural landscapes, World Heritage sites, protected areas and reserve museums, other legislative forms of cultural and natural heritage protection. Head, Division on Cultural Landscapes and Traditional Landuse, Dmitry Likhachev Russian Research Institute for Cultural and Natural Heritage (1992-2016). Postal address: 20, Bersenevskaya Naberezhnaya, Moscow, Russian Federation. Tel.: +7 (495) 686-13-19, mob.: +7 (917) 592-14-86. E-mail: culturalandscape@mail.ru

Аля иитирования:

Кулешова М. Е. Формы охраны природно-культурного наследия и категория культурного ландшафта [Электронный ресурс] // Горизонты гуманитарного знания. 2017, № 4. URL: http:// journals. mosgu.ru/ggz/article/view/580 (дата обращения: дд.мм.гггг.). DOI: 10.17805/ggz.2017.4.5 